\title{
PENGARUH LAYANAN BIMBINGAN KELOMPOK DENGAN METODE PEMBERIAN TUGAS TERHADAP KESULITAN BELAJAR SISWA KELAS X SEKOLAH MENENGAH ATAS NEGERI 1 GALUR TAHUN PELAJARAN 2018/2019
}

\author{
Anita Dewi Astuti \\ Program Studi Bimbingan dan Konseling \\ Fakultas Ilmu Pendidikan \\ IKIP PGRI Wates \\ E-mail: dewi_anita29@yahoo.com
}

\begin{abstract}
Abstrak
Kesulitan belajar merupakan salah satu permasalahan yang sering dialami oleh siswa dengan tingkatan yang bebeda-beda. Hal tersebut berpengaruh terhadap prestasi belajarnya, karena tidak semua siswa mempunyai prestasi belajar yang optimal. Tujuan dari penelitian ini adalah untuk mengetahui pengaruh layanan bimbingan kelompok dengan metode pemberian tugas terhadap kesulitan belajar siswa. Penelitian ini merupakan penelitian eksperimen, dengan menggunakan desain control group pre-test post-test sebagai populasinya adalah siswa kelas X SMA Negeri 1 Galur. Teknik sampling menggunakan random sampling dan purposive sampling, sedangkan teknik pengumpulan data menggunakan angket serta teknik analisis data menggunakan uji t (ttest). Berdasarkan hasil penghitungan uji t-test maka didapat nilai thitung $=3,095$ dan nilai $t$ tabel $=2,26$ dengan demikian thitung $>$ ttabel sehingga hipotesis kerja yang peneliti ajukan diterima. Hal ini membuktikan bahwa ada perbedaan antara rata-rata tingkat kesulitan belajar siswa dari hasil postest antara kelompok kontrol dan eksperimen sehingga layanan bimbingan kelompok dengan metode pemberian tugas dapat dikatakan efektif untuk mengatasi kesulitan belajar siswa.
\end{abstract}

Kata kunci: layanan bimbingan kelompok, pemberian tugas, kesulitan belajar

\begin{abstract}
Learning difficulties are one of the problems that are often experienced by students with different levels. This affects the learning achievement, because not all students have optimal learning achievement. The purpose of this study was to determine the effect of group counseling services on the method of giving assignments to student learning difficulties. This research is an experimental research, using the control group pre-test post-test design as the population is class $X$ students of SMA 1 Galur. The sampling technique uses random sampling and purposive sampling, while the data collection techniques use questionnaires and data analysis techniques using the t-test. Based on the results of the t-test test, the value of tcount $=3.095$ and the value of $t$ table $=2.26$ are obtained, thus tcount $>$ ttable so that the working hypothesis that the researcher submits is accepted. This proves that there is a difference between the average level of learning difficulties of students from the posttest results between the control and experimental groups so that group guidance services with the method of assigning tasks can be said to be effective in overcoming student learning difficulties.
\end{abstract}

Keywords: group guidance services, assignment of assignments, learning difficulties

Info Artikel

Diterima April 2019, disetujui Mei 2019, diterbitkan Juni 2019

Dipublikasikan Oleh: Program Studi Bimbingan dan Konseling Fakultas Keguruan dan Ilmu Pendidikan Universitas PGRI Yogyakarta 


\section{PENDAHULUAN}

Pendidikan sangat berperan dalam memajukan suatu bangsa dan masyarakat untuk menghasilkan sumber daya manusia yang berkualitas sebagai upaya mewujudkan cita-cita bangsa Indonesia. Keberhasilan pendidikan dapat dilihat dari nilai prestasi belajar yang dicapai oleh siswa. Ada beberapa faktor mempengaruhi keberhasilan belajar siswa, masing-masing faktor tersebut saling terkait dan tidak berdiri sendiri dalam mempengaruhi prestasi belajar siswa. Fakta di lapangan berkaitan dengan berbagai faktor yang mempengaruhi hasil prestasi belajar siswa, masih dijumpai bahwa tidak semua siswa memiliki prestasi belajar yang optimal. Setiap siswa pernah mengalami kesulitan belajar walaupun dalam tingkatan yang berbeda-beda.

Beragam karakteristik siswa dengan tingkat pengetahuan yang berbeda-beda menjadikan diantara mereka sulit untuk memahami materi yang sudah diajarkan, kurangnya latihan soal dan kurangnya persiapan menjelang ujian tengah semester maupun ujian akhir semester merupakan penyebab kesulitan siswa dalam mengerjakan soal ujian sehingga nilai rata-rata yang diperoleh peserta didik rendah. Hal ini sebagaimana dijelaskan oleh Irham dan Wiyani (2013 : 254) mengemukakan bahwa "kesulitan belajar merupakan kondisi saat siswa mengalami hambatan-hambatan tertentu untuk mengikuti proses pembelajaran dan mencapai hasil belajar secara optimal".

Ada beberapa faktor yang mempengaruhi terjadinya kesulitan belajar yang sangat berpengaruh terhadap hasil belajar peserta didik di sekolah. Faktor tersebut berasal dari dalam diri siswa maupun dari luar diri siswa, istilah lain menurut Slameto (2010: 54) menggolongkan menjadi dua faktor yaitu baik faktor intern maupun ektern. Lebih lanjut Syaiful Bahri Djamarah (2008 : 235) menegaskan bahwa faktor-faktor yang mempengaruhi kesulitan belajar adalah faktor internal yang berasal dari dalam diri sendiri misalnya bakat, minat dan kepribadan, serta faktor eksternal yang berasal dari luar diri seseorang misalnya faktor keluarga, sekolah, dan masyarakat. Disadari atau tidak dalam setiap waktu tidak jarang ditemukan siswa yang mengalami kesulitan belajar. Oleh karena itu berbagai usaha harus diupayakan dengan strategi dan pendekatan agar siswa dapat keluar dari masalah kesulitan belajar. Sebab apabila tidak terselesaikan maka siswa tersebut tidak meraih prestasi belajar yang memuaskan. 
Guru Bimbingan dan Konseling mempunyai peran dalam membantu siswa yang mengalami kesulitan belajar dengan berbagai layanan yang bisa diberikan kepada siswa, salah satunya adalah layanan bimbingan kelompok. Menurut Syamsu Yusuf (2006: 50) bimbingan kelompok merupakan pemberian bantuan kepada siswa melalui situasi kelompok. Masalah yang dibahas dalam bimbingan kelompok adalah yang bersifat common problem, masalah yang dialami bersama dan tidak rahasia, baik menyangkut masalah pribadi, sosial, belajar, maupun karir. Secara umum layanan bimbingan kelompok bertujuan untuk pengembangan kemampuan bersosialisasi, khususnya kemampuan berkomunikasi peserta layanan (peserta didik). Secara lebih khusus, layanan bimbingan kelompok bertujuan untuk mendorong pengembangan perasaan, pikiran, persepsi, wawasan dan sikap yang menunjang perwujudan tingkah laku yang lebih efektif, yakni peningkatan kemampuan berkomunikasi baik verbal maupun nonverbal pada peserta didik. Dalam pelaksanaan layanan bimbingan kelompok ada beberapa metode yang dapat diterapkan sesuai dengan kebutuhan dan permasalahannya. Salah satu metode yang dapat digunakan dalam mengentaskan masalah belajar peserta didik yaitu metode pemberian tugas.

Menurut Syaiful Bahri Djamarah dan Aswan Zain (2010 : 85) metode pemberian tugas adalah metode penyajian bahan dimana guru memberikan tugas agar siswa melakukan kegiatan belajar. Pemberian tugas ini bertujuan agar siswa memiliki prestasi belajar yang optimal, karena siswa melaksanakan latihan-latihan selama mengerjakan tugas. Oleh sebab itu pengalaman siswa dalam pelajaran dapat terarah dan diharapkan siswa dapat memecahkan atau menyelesaikan tugas yang diberikan oleh guru. Penerapan pemberian layanan dengan metode pemberian tugas dapat menumbuhkan semangat belajar siswa sehingga siswa lebih senang dalam belajar dan akan menyukai pelajaran dengan begitu siswa akan mudah untuk mengikuti pelajaran. Dinamika kelompok yang tercipta dalam suatu layanan bimbingan kelompok yang menerapkan metode pemberian tugas menjadikan siswa memperoleh jawaban atas permasalahan yang sedang mereka hadapi karena masing-masing anggota kelompok membantu memecahkan masalah yang dihadapi dalam kelompok atau pribadi.

Berdasarkan pengamatan yang dilakukan di SMA Negeri 1 Galur, masih dijumpai beberapa siswa yang mengalami kesulitan belajar seperti: sulit untuk mengatur waktu belajar, sulit akan memulai kegiatan belajar, sulit menentukan teknik belajar yang sesuai 
dengan dirinya. Hal ini dikuatkan dengan pendapatnya Abu Ahmadi dan Widodo Supriyono (2004 : 94) yang mengidentifikasi gejala-gejala siswa yang mengalami kesulitan belajar yaitu sebagai berikut : (1) Menunjukan prestasi yang rendah di bawah rata-rata yang dicapai oleh kelompok kelas, (2) Hasil yang dicapai tidak seimbang dengan usaha yang dilakukan, (3) Lambat dalam melakukan tugas belajar, (4) Menunjukkan sikap yang kurang wajar (acuh tak acuh, berpura-pura dusta), (5) Menunjukan tingkah laku yang berlainan (membolos, mudah tersingung, murung, pemarah, bingung, cemberut, sedih.)

Gejala-gejala di atas dimungkinkan muncul karena siswa belum mengetahui faktor penyebab dari kesultan belajar. Selain itu pelaksanaan layanan bimbingan kelompok di sekolah belum berjalan secara optimal. Dalam layanan bimbingan kelompok masih terbatas diskusi maupun ceramah sehingga belum dapat merangkul semua permasalahan siswa terutama yang berkaitan dengan kesulitan belajar serta belum dilakukannya layanan bimbingan kelompok dengan metode pemberian tugas untuk membimbing siswa agar tidak mengalami masalah kesulitan belajar di sekolah maupun di rumah.

Penelitian ini dimaksudkan untuk memecahkan permasalahan tentang apakah ada pengaruh penggunaan layanan bimbingan kelompok dengan metode pemberian tugas terhadap kesulitan belajar siswa?. Dari hasil penelitian ini diharapkan dapat membantu mengatasi masalah kesulitan kesulitan belajar yang dialami siswa sehingga nantinya siswa dapat memiliki prestasi belajar yang optimal.

\section{METODE PENELITIAN}

Metode penelitian yang dipakai adalah penelitian kuantitatif dengan jenis penelitian eksperimen. Desain penelitian yang digunakan yaitu control group pre-test post-test. Dalam penelitian ini yang menjadi populasi adalah siswa kelas X SMA Negeri 1 Galur Tahun Pelajaran 2018/2019. Teknik pengambilan sampel menggunakan random sampling dan purposive sampling. Teknik random sampling adalah pengambilan sampel dengan cara undian. Adapun prosedur pengambilan sampel dengan teknik random sampling yaitu dengan cara mengundi kelasnya untuk dijadikan kelompok eksperimen dan kelompok kelompok kontrol. Dalam penelitian ini yang menjadi kelompok eksperimen adalah kelas X IPS 1 dan kelompok kontrolnya adalah kelas X IPS 2. 
Setelah terpilih dua kelas masing-masing kelas diambil secara purposive random sampling sebanyak 10 orang dengan tujuan mengambil siswa yang memiliki kesulitan belajar tinggi untuk dijadikan sebagai sampel dalam kelompok kontrol dan kelompok eksperimen. Teknik pengumpulan data menggunakan angket. Dari hasil uji coba angket dari 50 butir terdapat 10 item yang dinyatakan tidak valid karena nilai $\mathrm{r}$ hitung kurang dari 0,3. Sedangkan reliabilitas angket yaitu 0,926. Teknik analisis data menggunakan uji $\mathrm{t}$ (t-test), dengan persyaratan uji analisis menggunakan uji normalitas dan homogenitas dengan taraf signifikansi $5 \%$.

\section{HASIL PENELITIAN DAN PEMBAHASAN}

Berdasarkan hasil analisis angket tentang kesulitan belajar siswa kelas X Sekolah Menengah Atas Negeri I Galur tahun ajaran 2018/2019 diperoleh hasil bahwa:

1. Deskripsi Data Kesulitan Belajar Pada Kelompok Kontrol

Data variabel kesulitan belajar untuk kelompok kontrol pada pretes diperoleh nilai tertinggi $=120$, nilai terendah $=92$, range $=28$, rata-rata $=109,00$. Dari deskripsi tersebut akan disajikan dalam bentuk tabel sebagai berikut:

Tabel 1.

Distribusi Frekuensi Data Pretest Kelompok Kontrol

\begin{tabular}{|c|l|c|}
\hline Kelas & Nilai Statistik & Frekuensi \\
\hline 1 & $92-97$ & 2 \\
\hline 2 & $98-103$ & 0 \\
\hline 3 & $104-109$ & 3 \\
\hline 4 & $110-115$ & 2 \\
\hline 5 & $116-121$ & 3 \\
\hline \multicolumn{2}{|c|}{ Jumlah } & $\mathbf{1 0}$ \\
\hline
\end{tabular}

Berdasarkan data di atas setelah dimasukkan kedalam klasifikasi penggolongan skor tingkat kesulitan belajarnya didapat 5 siswa (50\%) masuk dalam ketegori tinggi, sedang 3 siswa (30\%) dalam kategori sedang dan sisanya 2 siswa (20\%) masuk dalam kategori rendah. Dari dari data ini dapat disimpulkan bahwa sebagian besar siswa yang dijadikan sampel dalam kelompok kontrol inicmasih memiliki kesulitan belajar dalam ketegori tinggi. Sedangkan untuk postest kelompok kontrol didapat data sebagai berikut: 
Tabel 2.

Distribusi Frekuensi Data Postest Kelompok Kontrol

\begin{tabular}{|c|l|c|}
\hline Kelas & Nilai Statistik & Frekuensi \\
\hline 1 & $109-113$ & 2 \\
\hline 2 & $114-118$ & 1 \\
\hline 3 & $119-123$ & 4 \\
\hline 4 & $124-128$ & 2 \\
\hline 5 & $129-133$ & 1 \\
\hline \multicolumn{2}{|c|}{ Jumlah } & $\mathbf{1 0}$ \\
\hline
\end{tabular}

Dari tabel di atas berdasarkan klasifikasi penggolongan kriteria didapatkan hasil sebanyak 5 siswa (50\%) masuk dalam ketegori tinggi, 4 siswa (40\%) masuk dalam kategori sedang dan sisanya sebanyak 1 siswa (10\%) masuk dalam kategori rendah. Tidak berbeda jauh dari hasil pretest kelompok kontrol, untuk hasil postest kelompok kontrol masih memiliki rata-rata yang sama tingkat kesulitan belajarnya dimana 5 siswa masuk dalam kategori tinggi.

2. Deskripsi Data Kesulitan Belajar Pada Kelompok Eksperimen

Berbeda dengan data yang diperoleh pada pretest kelompok kontrol, untuk pretest kelompok eksperimen diperoleh data sebagai berikut:

Tabel 3.

Distribusi Frekuensi Data Pretest Kelompok Eksperimen

\begin{tabular}{|c|l|c|}
\hline Kelas & Nilai Statistik & Frekuensi \\
\hline 1 & $104-106$ & 3 \\
\hline 2 & $107-109$ & 2 \\
\hline 3 & $110-112$ & 3 \\
\hline 4 & $113-115$ & 1 \\
\hline 5 & $116-118$ & 1 \\
\hline \multicolumn{2}{|c|}{ Jumlah } & $\mathbf{1 0}$ \\
\hline
\end{tabular}

Berdasarkan data di atas setelah dimasukkan kedalam klasifikasi penggolongan skor tingkat kesulitan belajarnya didapat 1 siswa (10\%) masuk dalam ketegori tinggi, sedang 4 siswa (40\%) dalam kategori sedang dan sisanya 5 siswa $(50 \%)$ masuk dalam kategori rendah. Sedangkan untuk postest kelompok eksperimen didapat data sebagai berikut: 
Tabel 4.

Distribusi Frekuensi Data Postest Kelompok Eksperimen

\begin{tabular}{|c|l|c|}
\hline Kelas & Nilai Statistik & Frekuensi \\
\hline 1 & $108-110$ & 4 \\
\hline 2 & $111-113$ & 3 \\
\hline 3 & $114-116$ & 2 \\
\hline 4 & $117-119$ & 0 \\
\hline 5 & $120-122$ & 1 \\
\hline \multicolumn{2}{|c|}{ Jumlah } & $\mathbf{1 0}$ \\
\hline
\end{tabular}

Berdasarkan data di atas setelah dimasukkan kedalam klasifikasi penggolongan skor tingkat kesulitan belajarnya didapat 2 siswa (20\%) masuk dalam ketegori tinggi, sedang 4 siswa (40\%) dalam kategori sedang dan sisanya 4 siswa (40\%) masuk dalam kategori rendah.Untuk melihat efektivitas dari tindakan yang telah diberikan maka dapat dilalukan uji komparasi dengan menggunakan $\mathrm{t}$ test. Pengujian dilakukan dengan bantuan program SPSS for windows diperoleh nilai t hitung sebesar sebesar 3,095. Sedangkan t tabel dengan taraf signifikansi 5\%, df 9 sebesar 2,26. Berdasarkan hasil analisis t test dapat disimpulkan bahwa t hitung lebih besar dari t tabel $(3,095>2,26)$. Dengan demikian layanan bimbingan kelompok dengan metode pemberian tugas efektif untuk mengatasi kesulitan belajar siswa.

Melalui layanan bimbingan kelompok dengan metode pemberian tugas mendorong siswa untuk mengerjakan tugas dengan sungguh-sungguh sehingga akhirnya siswa memiliki hasil belajar yang lebih mantap. Hal ini dikuatkan dengan pendapatnya Roestiyah (2001: 133) yang menyatakan bahwa metode pemberian tugas bertujuan memperoleh, memperluas, dan memperkaya pengetahuan dan keterampilan dengan melaksanakan tugas sehingga siswa akan terangsang lebih aktif dalam belajarnya.

Siswa yang awalnya memiliki kesulitan belajar karena keadaan dimana siswa tidak mendapatkan kesempatan yang memadai untuk berkembang sesuai dengan kapasitasnya sehingga menghambat tercapainya kinerja akademik yang sesuai dengan harapan ( Muhibbin Syah, 2008:184), dengan metode pemberian tugas ini menjadikan siswa bisa lebih terangsang untuk belajar lebih baik, memupuk inisiatif dan berani bertanggung jawab sendiri. Oleh karena itu sangat tepat jika layanan bimbingan kelompok dengan metode pemberian tugas ini diberikan untuk membantu siswa dalam mengatasi kesulitan belajarnya, sehingga jika masalah yang dialami segera diatasi maka 
dapat menimbulkan dampak positif bagi keberhasilan siswa terutama dalam meraih prestasi belajar yang optimal.

\section{KESIMPULAN}

Kesulitan belajar merupakan salah satu permasalahan yang sering dialami oleh siswa seperti: sulit mengatur waktu, sulit untuk memulai kegiatan belajar, sulit menentukan teknik belajar dan lain sebagainya. Oleh karena itu perlu pendampingan dari guru Bimbingan dan konseling untuk menemukan faktor penyebab dari kesulitan belajar yang dialaminya yaitu dengan memberikan layanan bimbingan kelompok dengan metode pemberian tugas.

Berdasarkan hasil analisis dari data penelitian yang telah dilakukan taerhadap siswa kelas X SMA Negeri 1 Galur tahun pelajaan 2018/2019 dengan jumlah sampel sebanyak 10 siswa dari kelompok kontrol dan 10 dari kelompok ekperimen dengan menggunakan teknik analisis statistik komparatif dan pengujian tersebut dilakukan dengan menggunakan program SPSS for Windows maka didapatkan hasil t-hitung = 3,095. Sedangkan t-hitung > t-tabel $(3,095>2,26)$ maka hipotesis yang digunakan Ha : "Ada Pengaruh Layanan Bimbingan Kelompok dengan Metode Pemberian Tugas Terhadap Kesulitan Belajar Siswa Kelas X SMA Negeri 1 Galur tahun pelajaran 2018/2019" dapat diterima.

\section{DAFTAR PUSTAKA}

Ahmadi, A dan Widodo. (2004). Psikologi Belajar. Jakarta : Rineka Cipta.

Djamarah, S.B dan Zain, A. (2010). Strategi Belajar Mengajar.Jakarta:RinekaCipta.

Djamarah, S.B. (2008). Psikologi Belajar. Jakarta: Renika Cipta.

Irham, M. dan Wiyani, N. A. (2013). Psikologi Pendidikan : Teori dan aplikasi dalam proses pembelajaran. Jogjakarta: Ar-ruzz Media.

Roestiyah. (2001). Strategi Belajar Mengajar .Jakarta : Renika Cipta.

Slameto. (2010). Belajar dan Faktor-Faktor yang Mempengaruhi. Jakarta: Rineka Cipta.

Syah, M. (2008). Psikologi Belajar. Jakarta : PT Raja Grafindo Persada.

Yusuf, S. (2006). Landasan Bimbingan dan Konseling. Bandung : Rosda. 